\title{
Understanding the degree of awareness among medical professionals regarding the ethics of pharmaceutical marketing activities in context of revised medical council of India code of ethics
}

\author{
Renuka H. Munshi ${ }^{1}$, Kanchan R. Singh ${ }^{2 *}$, Astha D. Thakkar ${ }^{3}$
}

\begin{abstract}
${ }^{1}$ Department of Clinical Pharmacology, ${ }^{2}$ Department of Pharmacology, ${ }^{3}$ Undergraduate student, Topiwala National Medical College \& BYL Nair Ch. Hospital, Mumbai-400008, Maharashtra, India

Received: 12 February 2016

Revised: 22 February 2016

Accepted: 23 February 2016

\section{*Correspondence to: \\ Dr. Kanchan Rao Singh, \\ Email: drkanchan21@ \\ gmail.com}

Copyright: @ (the author(s), publisher and licensee Medip Academy. This is an openaccess article distributed under the terms of the Creative Commons Attribution NonCommercial License, which permits unrestricted noncommercial use, distribution, and reproduction in any medium, provided the original work is properly cited.

\begin{abstract}
Background: Pharmaceutical marketing activities are regarded as ethically challenging by most medical professionals. This study was planned to understand the extent of the interaction of pharmaceutical companies with healthcare providers \& to determine the level of awareness about the 'Medical Council of India (MCI) Code of Ethics'.

Methods: A questionnaire based survey was conducted among 100 consultants and residents. The questionnaire mainly dealt with ethical issues about accepting free gifts, medicines and other sponsorships from pharmaceutical representatives, interactions and expectations from representatives of pharmaceutical companies by doctors and ascertaining among them the level of awareness about the MCI's code of ethics.

Results: $59.4 \%$ residents and 58.8\% consultants do not consider small gifts (stationery/books/drug samples) as ethically problematic. $88 \%$ residents and $85 \%$ consultants felt that offers should be limited. $72 \%$ of consultants were aware of the revised MCI code of ethics as compared to $28 \%$ of residents.

Conclusions: Most physicians do maintain a code of ethics with regards to accepting gifts and they felt that inexpensive gifts do not influence clinical judgment. Consultants were of the view that amended MCI code of ethics would not affect their clinical practice significantly.
\end{abstract}

Keywords: Codes of ethics, Medical workforce, Pharmaceutical marketing, Gifts

\section{INTRODUCTION}

As per the International code of medical ethics of the world medical association (1949), "a doctor must always maintain the highest standards of professional conduct and must practice his profession uninfluenced by motives of profit". ${ }^{1}$ The medical council of India (MCI) too has listed regulations relating to the professional conduct, etiquette and ethics for registered medical practitioners as per the Indian medical council act, 1956 (102 of 1956), the main purpose of which is that a physician shall uphold the dignity and honour of his profession and his prime objective would be to render service to humanity; reward or financial gain should be a subordinate consideration. $^{2}$
The important difference between the ordinary consumer goods \& the sale of prescription drugs is that the sale of drugs does not take place directly between the producer and the consumer. In this case, the process is mediated by the physician who prescribes a particular medication. Pharmaceutical sales practices often involve ways to influence physician's recognition of the drug so that it remains on his/her top of mind. ${ }^{3}$ The pharmaceutical industry spends a significant amount of resources on marketing its products. According to one estimate, the top 50 Indian pharmaceutical companies spend $290 \%$ to $1,025 \%$ more on marketing than on research and development. ${ }^{4}$ Such a high rigor of marketing activities may spark a conflict of interest (COI) in the mind of the physician who will be treating his/her patients by prescribing the drugs. The physician might be compelled 
to choose a drug which has either lower efficacy or is priced higher or even both. This hampers the patient's condition medically as well as financially.

Keeping in mind the fact that medical professionals may be ignoring the ethics of their profession and getting influenced by the aggressive marketing strategies of the pharmaceutical industry, the MCI defined a modified code of ethics for doctors. The MCI has recently amended its code of ethics in December 2009 which bans the physicians from accepting any kinds of gifts from pharmaceutical companies. As per the notification, if a complaint against the violation of the code of ethics by a physician is filed with the MCI, the registration of the offending physician can be cancelled. ${ }^{5}$

Thus, the goal of the present study was to assess the kind of interactions representatives and medical professionals (residents and doctors). This study also assessed the extent to which dealings of medical professionals with pharmaceutical companies were likely to provoke a COI in the prescribing habits of a doctor $\&$ aimed to find out the extent of awareness \& compliance of the guidelines of the amended code by MCI.

A secondary objective of the study was to spread awareness about the revised MCI code of ethics especially among medical residents as they are the ones who are more likely to have a full-fledged interaction with the drug industry in the near future.

\section{METHODS}

The study was approved by the Institutional ethics committee. A questionnaire based survey was conducted among 100 consultants and residents respectively. The questionnaire dealt with ethical issues about accepting sponsorships \& individual interactions of physicians with pharmaceutical companies \& ascertaining the level of awareness about the MCI's revised code of ethics.

The responses received were coded and made anonymous so that the confidentiality of the respondent was maintained. Their response to the questionnaire was analysed in percentages; with the use of descriptive statistics.

\section{RESULTS}

Most of the residents (59.4\%) and consultants (58.8\%) did not consider the offers of small gifts such as pens, writing pads and free drug samples as ethically problematic issues. However, accepting expensive gifts, such as sponsored dinners/all-paid holidays was considered ethically problematic in case of $85 \%$ consultants and $77 \%$ residents. The most commonly offered gifts included stationery, torches, stethoscopes, books, journals, magazines and sometimes, kitchenware. $88 \%$ residents and $85 \%$ consultants feel that there should be a limit to such offers. Regarding accepting sponsorship from pharmaceutical companies for conferences/CMEs, $60 \%$ of the consultants and $51 \%$ residents felt that such sponsorships were necessary. However, only 5\% of residents and $3 \%$ of consultants claimed that they accepted these offers very often. $21 \%$ residents and $12 \%$ consultants said they were occasionally offered sponsorships for the research projects that they conducted. However, $66 \%$ residents and $56 \%$ consultants are unaware of the guidelines that should be followed when accepting such sponsorships. 59\% residents and 62\% consultants also feel that sponsorships for research should be limited as they could lead to promotion $\&$ advertising of the company's products. $72 \%$ of the doctors did not feel obliged to return favours in the forms of gifts \& sponsorships made by the pharmaceutical companies by prescribing their medications. An interesting observation was that $72 \%$ of the consultants were aware of the revised MCI code of ethics as compared to a meagre $28 \%$ of the residents (Table 1).

\section{DISCUSSION}

The physician-patient relationship is a fiduciary relationship. Fiduciaries have an obligation to avoid conflicts of interest. Most of the doctors (residents and consultants) attend to drug representatives on a daily basis. The drug company representative offer gifts to physician in order to increase the prescription of drugs manufactured by the company. The gifts range anything from a small pen carrying the name of the drug to a dinner or weekend get-away sponsored by the company.

Prior to the revised MCI code which was introduced in year 2009, the practice of giving gifts, offering foreign trips, and even direct cash incentives to doctors by drug companies was reported to be rampant. It was believed to be much more common in areas such as cardiology where the stakes were higher. ${ }^{6}$ Even small gifts produce in their recipients a disproportionately powerful willingness to reciprocate in some manner. ${ }^{3}$ This creates a bias in the mind of the doctor wherein he has to decide between the drug which is most efficacious for his patient and the drug whose parent company sponsored the weekend trip! Although most consultants deny their professional integrity can be "bought" by something as trivial as a cup of coffee or a free lunch, there is evidence available which suggests that physician behaviour with respect to drugs may be associated with drug company promotional activities. $^{7-12}$

The term 'promotion' means those informational and marketing activities, the purpose of which is to induce prescribing, supply or administration of medical products. This includes the activities of medical representatives and all other aspects of sales promotion such as journal and direct mail advertising; participation in conference exhibitions; the use of audio-visual materials; the provision of drug samples, gifts and hospitality for medical professionals and seminars. ${ }^{13}$ The pharmaceutical promotion and marketing expenditure in last decade was 
reported to be on average of $20-30 \%$ of sales turnover or about two to three times the average expenditure on research and development. ${ }^{14}$ The details of the pharmaceutical industry strategies to \& their budget allocations is mentioned in figure $1 .^{4}$

Table 1: Observation table on the results.

\begin{tabular}{|c|c|c|}
\hline Parameter assessed & $\begin{array}{l}\text { Resident } \\
\text { doctors } \\
(\mathbf{n}=\mathbf{1 0 0})\end{array}$ & $\begin{array}{l}\text { Consultants } \\
(n=100)\end{array}$ \\
\hline $\begin{array}{l}\text { 1. The small gifts } \\
\text { (pens, writing pads, } \\
\text { free drug samples, } \\
\text { etc.) not problematic }\end{array}$ & $\begin{array}{l}57(59.4 \%) \\
(\mathrm{n}=96) \\
6 \text { participants } \\
\text { chose not to } \\
\text { answer this } \\
\text { question }\end{array}$ & $\begin{array}{l}57(58.8 \%) \\
(\mathrm{n}=97) \\
3 \text { participants } \\
\text { chose not to } \\
\text { answer this } \\
\text { question }\end{array}$ \\
\hline $\begin{array}{l}\text { 2. Sponsored dinners, } \\
\text { overseas trips are } \\
\text { problematic }\end{array}$ & $\begin{array}{l}77 \\
(n=100)\end{array}$ & $\begin{array}{l}85 \\
(n=100)\end{array}$ \\
\hline $\begin{array}{l}\text { 3. There should be a } \\
\text { limit to offers of } \\
\text { expensive gifts }\end{array}$ & $\begin{array}{l}88 \\
(n=100)\end{array}$ & $\begin{array}{l}85 \\
(n=100)\end{array}$ \\
\hline $\begin{array}{l}\text { 4. Sponsorship of } \\
\text { CMEs/conferences by } \\
\text { pharmaceutical } \\
\text { companies is } \\
\text { necessary }\end{array}$ & $\begin{array}{l}51 \\
(n=100)\end{array}$ & $\begin{array}{l}60 \\
(n=100)\end{array}$ \\
\hline $\begin{array}{l}\text { 5. Have often accepted } \\
\text { sponsorships for } \\
\text { research projects }\end{array}$ & $\begin{array}{l}5 \\
(n=100)\end{array}$ & $\begin{array}{l}3 \\
(n=100)\end{array}$ \\
\hline $\begin{array}{l}\text { 6. Was occasionally } \\
\text { offered sponsorship } \\
\text { for research projects } \\
\text { by pharmaceutical } \\
\text { companies }\end{array}$ & $\begin{array}{l}21 \\
(n=100)\end{array}$ & $\begin{array}{l}12 \\
(n=100)\end{array}$ \\
\hline $\begin{array}{l}\text { 7. Unaware of MCI } \\
\text { guidelines for } \\
\text { accepting company } \\
\text { grants for projects }\end{array}$ & $\begin{array}{l}66 \\
(n=100)\end{array}$ & $\begin{array}{l}56 \\
(n=100)\end{array}$ \\
\hline $\begin{array}{l}\text { 8. The company } \\
\text { sponsorship should } \\
\text { not be provided for } \\
\text { research projects since } \\
\text { this could lead to } \\
\text { prescription bias }\end{array}$ & $\begin{array}{l}59 \\
(n=100)\end{array}$ & $\begin{array}{l}62 \\
(n=100)\end{array}$ \\
\hline $\begin{array}{l}\text { 9. Receiving small } \\
\text { gifts/sponsorship of } \\
\text { CMEs does not lead to } \\
\text { prescription bias }\end{array}$ & $\begin{array}{l}72 \\
(n=100)\end{array}$ & $\begin{array}{l}72 \\
(n=100)\end{array}$ \\
\hline $\begin{array}{l}\text { 10. Aware of the } \\
\text { overall MCI code of } \\
\text { ethics }\end{array}$ & $\begin{array}{l}28 \\
(n=100)\end{array}$ & $\begin{array}{l}72 \\
(n=100)\end{array}$ \\
\hline
\end{tabular}

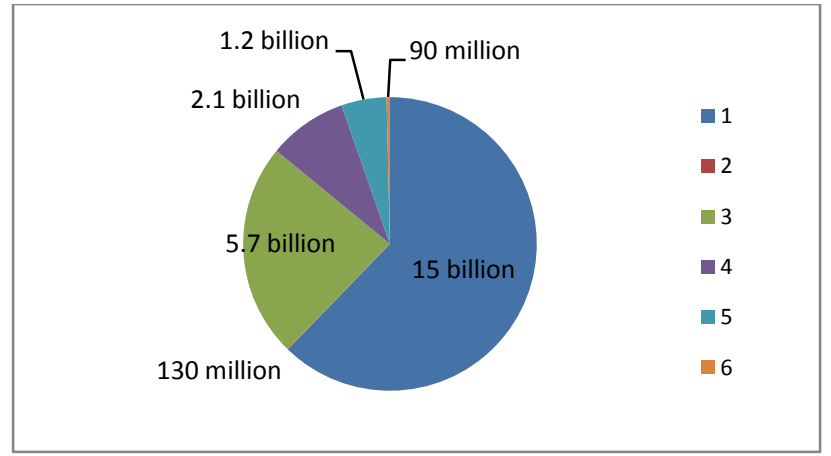

1. Detailing (face-to-face sales and promotional activities) 2 . Clinical trials, 3. Samples, 4. Educational and promotional meetings, 5. Advertisements, 6. Direct-to-consumer advertising, (Source: Cegedim Strategic Data, 2012 U.S. Pharmaceutical Company Promotion Spending) ${ }^{4}$.

\section{Figure 1: Expenditure by type of marketing activity.}

A review showed that meetings with pharmaceutical representatives were associated with increased requests by doctors for their drugs to be added to the hospital formulary and to changes in prescribing practice, while attending sponsored educational events and receiving funding were associated with increased prescription rates of the sponsor's medication. ${ }^{8}$

The results of a study conducted in the USA to assess the extent of pharmaceutical industry contact with trainees, their attitudes about these interactions and effects on trainee prescribing behaviour showed that the pharmaceutical industry had a significant presence during residency training, was acceptable to the residents and their presence did influence prescribing behaviour. ${ }^{15}$

A National survey of physicians in the US found that 94\% physicians are involved in marketing relationships with pharmaceutical companies and accept some form of industry gifts or payments. ${ }^{16}$ Another survey found that physicians were significantly less likely than patients to believe that industry gifts are influential with just $9 \%$ of physicians believing that a small textbook is influential compared to $37 \%$ of patients. ${ }^{17}$

Another study carried out to assess the opinions and practice patterns of obstetrician-gynaecologists on acceptance and use of free drug samples and other incentive items from pharmaceutical representatives showed that most obstetrician-gynaecologists considered free drug samples as appropriate gifts, these samples were most commonly judged to be influential on prescribing practices. ${ }^{18}$

All this evidence point out to a serious problem of medical malpractice in terms of sales of inferior drugs at higher prices rather than choosing more efficacious drugs. In addition to the off beam prescribing of drugs, there are faults in the research projects sponsored by pharmaceutical companies also. 
In order to curb these practices, the MCI amended the Indian Medical Council (Professional Conduct, Etiquette and Ethics) Regulations, 2002 and has added a new clause 6.8 in the Chapter 6 on unethical acts. ${ }^{5,19}$ This clause describes the code of conduct for doctors and professional association of doctors in their relationship with pharmaceutical and allied health sector industry. The code prohibits a medical practitioner from receiving a) any gift b) any travel facility for self and family members for vacation or for attending conferences, seminars, workshops, CME programs, etc. as a delegate c) any hospitality like hotel accommodation for self and family members under any pretext or d) any cash or monetary grants for individual purpose in individual capacity under any pretext from the industry.

Thus, the aim of our study was to assess the kind of interactions that takes place between a pharmaceutical company representative and a medical professional (residents and doctors). We also wished to assess the extent to which dealings of medical professionals with pharmaceutical companies were likely to provoke a COI in the prescribing habits of a doctor. Our study also aimed to find out the extent of awareness of the guidelines of the amended code and if the consultants were complying with the guidelines.

The study results show that that a majority of medical professionals do not consider the offer of small value items viz. stationery, books and free drug samples as ethically problematic issues. They felt that these small gifts, being of trivial value, were unlikely to cloud their judgement regarding drug therapy. The free drug samples generally provided were used for poor unaffording patients rather than being used by the physician for personal purposes.

A favourable response seen was that doctors considered the offers of dinners and all-expense paid trips as hugely problematic. According to the revised MCI code of ethics, consultants are barred from accepting all kinds of gifts from pharmaceutical companies. Most of the consultants accept small gifts but only a few $(<10 \%)$ of the doctors accept all-expense paid trips. This shows that in a majority of doctors, there exists an inherent code of ethics which prompts them not to do anything which has a potential to harm the patient.

Most doctors agree that sponsorships for research and conducting conferences are necessary as they are the major source of funds. Consultants strongly feel that the attendance to such conferences/CMEs would drop significantly if pharmaceutical companies stop sponsoring them. Conferences are used as a platform to discuss new and existing drugs and to decide which one will by best suited to the patient, rather than the conference being focused on the drugs made by the company. Their opinion was that as research projects require a lot of funding which would otherwise be impossible to conduct especially in public sector scenarios, sponsorship from pharmaceutical companies is necessary. Another school of thought is research funding should be limited as it will limit unnecessary prescription and decrease cost burden to patients and help implement rational drug therapy. Also the amount of sponsorship may put some pressure on the researcher to highlight some aspects the company is interested in advertising.

A major disparity between residents and consultants was regarding awareness about the revised MCI Code of Ethics. Only $28 \%$ residents were aware of it compared to $72 \%$ consultants. This is as predicted in the beginning of the study that the MCI Code of Ethics, being a recent amendment, will take time to seep into the minds of the doctors.

$60 \%$ of the doctors feel that the revised MCI Code of Ethics will not have any significant implications on their clinical practice as they do not rely on pharmaceutical companies for anything. Some other doctors feel that it will make the doctor-patient relationship more transparent. Doctors also have propounded that the implementation of the code of ethics will have a significant impact on the conferences/CMEs which are conducted in the future, there might not be enough financial resources available in order to conduct the conference. This tells us that most of the medical practice is clean and ethical. However, the doctors who have refused to respond to the study are probably being engaged in some or the other unethical practice due to which they have refused to participate in the study after having been explained the purpose and aims of the study. They have felt that the questions are way too straightforward for them to give an answer and have also put forward the view that very few doctors will be truthful to the questionnaire.

Our results are comparable to other published surveys that have examined the attitudes of physicians regarding gifts from the pharmaceutical industry and encounters with pharmaceutical representatives..$^{9,17,29-33}$ It has been noted that most physicians deny that gifts could influence their behaviour, and that most physicians are equivocal about the appropriateness of gifts from pharmaceutical representatives. Overall, the responses to our survey reflect the point that the type and monetary value of gifts determine their ethical propriety among physicians.

\section{CONCLUSIONS}

Hence the authors conclude their observations that although not all the consultants and residents are aware of every rule that exists, there sure is a sense of goodwill in them for their patients. They keep the old principle of Primum non nocere above anything else. The code of ethics has evolved as per the requirements of the society. It and should be examined from time to time to understand if it needs to be updated or made more specific. 
Funding: Indian Council of Medical Research through short-term studentship

Conflict of interest: None declared

Ethical approval: The study was approved by the Institutional Ethics Committee

\section{REFERENCES}

1. International code of medical ethics of the world medical association, 1949. Available at http://www.cirp.org/library/ethics/intlcode/;

Accessed 1 February 2016.

2. Indian medical council (professional conduct, etiquette and ethics) regulations, 2002. Available at http://mohfw.nic.in/code.htm. Accessed on $1^{\text {st }}$ February 2016.

3. Wall LL, Brown D. The high cost of free lunch. Obstetr Gynecol. 2007;110(1):169-73.

4. Persuading the prescribers: pharmaceutical industry. Marketing and its influence on physicians and patients. 2013. Available at http://www.pewtrusts.org/en/research-and-analysis/ fact-sheets/2013/11/11/persuading-the-prescriberspharmaceutical-industry-marketing-and-its-influence -on-physicians-and-patients. Accessed on 1 February 2016.

5. Medical council of India code of ethics regulations, 2002. Amendment Notification New Delhi, 2009. Available at http://www.mciindia.org/ KNOW/ rules/ethics.htm. Accessed on 1 February 2016.

6. McGuaran A. Royal college issues new guidelines on gifts from drugs companies BMJ. 2002;325(7363):511.

7. Liu YM, Yang YH, Hsieh CR. Financial incentives and physicians' prescription decisions on the choice between brand-name and generic drugs: evidence from Taiwan. J Health Econ. 2009;28:341-9.

8. Wazana A. Physicians and the pharmaceutical industry. Is a gift ever just a gift? JAMA. 2000;283:373-80.

9. McKinney WP, Schiedermayer DL, Lurie N, Simpson DE, Goodman JL, Rich EC. Attitudes of internal medicine faculty and residents toward professional interaction with pharmaceutical sales representatives. JAMA. 1990;264:1693-7.

10. Bowman MA, Pearle DL. Changes in drug prescribing patterns related to commercial company funding of continuing medical education. J Cont Educ Health Prof. 1988;8:13-20.

11. Orlowski JP, Wateska L. The effects of pharmaceutical firm enticements on physician prescribing patterns. Chest. 1992;102:270-3.

12. Bowman MA. The impact of drug company funding on the content of continuing medical education. Mobius. 1986;6:66-9.

13. Walker G. Code of practice for the pharmaceutical Industry. In: ABPI Data Sheet Compendium. Association of British Pharmaceutical Industry. London: Datapharm Publications; 1993:VI-XIII.
14. Editorial. Drug promotion: stealth, wealth and safety. Lancet. 1993;341:1507-8.

15. Zipkin DA, Steinman MA. Interactions between pharmaceutical representatives and doctors in training. J Gen Intern Med. 2005;20(8):777-86.

16. Campbell E, Gruen R, Mountford J, Miller L, Clearly P, Blumenthal D. A national survey of physician-industry relationships. $\mathrm{N}$ Engl J Med. 2007;356:1742-50.

17. Gibbons R, Landry F, Blouch D, Jones DL, Williams FK, Lucey CR et al. A comparison of physicians' and patients' attitudes toward pharmaceutical industry gifts. J Gen Intern Med. 1998;13:151-4.

18. Randall ML, Rosenbaum JR, Rohrbaugh RM, Rosenheck RA. Attitudes and behaviors of psychiatry residents toward pharmaceutical representatives before and after an educational intervention. J Med Ethics. 2006;32(10):559-63.

19. Gulhati CM. Marketing of medicines in India. BMJ. 2004; 328:778-9.

20. Ziegler MG, Lew P, Singer BC. The accuracy of drug information from pharmaceutical sales representatives. J American Med Assoc. 1995;273:1996-8.

21. Caudill T, Johnson M, Rich E, McKinney P. Physicians, pharmaceutical sales representatives, and the cost of prescribing. Arch Fam Med. 1996;5:201-6.

22. Bower A, Burkett G. Family physicians and generic drugs: a study of recognition, Information sources, prescribing attitudes, and practices. J Fam Pract 1987;24:612-6.

23. Bhatt AD. Drug promotion and doctor: a relationship under change? J Postgrad Med. 1993;39:120-3.

24. Bal A. Can the medical profession and the pharmaceutical industry work ethically for better health care? Indian J Med Ethics. 2004;1:17-8.

25 . Roy N. Who rules the great Indian drug bazaar? Indian J Med Ethics. 2004;1:2-3.

26. Anand AC. The pharmaceutical industry: Our 'silent partner' in the practice of medicine. Natl Med J India. 2000;13:319-21.

27. Kalantri SP. Drug industry and medical conferences. Indian J Anaesth. 2004;48:28-30.

28. Verma SK. Physician-pharmaceutical industry interaction: changing dimensions and ethics. Indian Pediatr. 2004;41:29-36.

29. Banks JW, Mainous AG. Attitudes of medical school faculty toward gifts from the pharmaceutical industry. Acad Med. 1992;67:610-2.

30. Lichstein PR, Turner RC, O'Brien K. Impact of pharmaceutical company representatives on internal medicine residency programs: a survey of residency program directors. Arch Intern Med. 1992;152:100913.

31. Brotzman GL, Mark DH. The effect on resident attitudes of regulatory policies regarding 
pharmaceutical representative activities. J Gen Intern Med. 1993;8:130-4.

32. Poirier TI, Giannetti V, Guidici RA. Pharmacists' and physicians' attitudes toward pharmaceutical marketing practices. Am J Hosp Pharm. 1994;51:378-81.
33. Steinman MA, Shlipak MG, McPhee SJ. Of principles and pens: attitudes and practices of medicine house staff toward pharmaceutical industry promotions. Am J Med. 2001;110:551-7.

Cite this article as: Munshi RH, Singh KR, Thakkar $\mathrm{AD}$. Understanding the degree of awareness among medical professionals regarding the ethics of pharmaceutical marketing activities in context of revised medical council of India code of ethics. Int $\mathbf{J}$ Basic Clin Pharmacol 2016;5:263-8. 